\title{
Identification of a common deletion region in $10 q 26$ associated with human gliomas
}

\author{
Margarida Alves ${ }^{1,2}$, Paulo Liberato ${ }^{1}$, Ana Rita Conde ${ }^{1,2}$, Manuela Mafra ${ }^{3}$, Alexandra Inverno ${ }^{4}$, Ana Teresa Maia ${ }^{5}$,

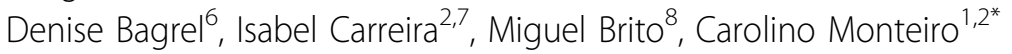 \\ From 16th International Charles Heidelberger Symposium on Cancer Research \\ Coimbra, Portugal. 26-28 September 2010
}

Gliomas are the most frequent primary tumours of the central nervous system and several types of gliomas are histopathologically recognized. Loss of the whole chromosome 10, or part of it, is the most prevalent genetic abnormality in astrocytic tumours, particularly in glioblastomas, in which it is observed in up to $80 \%$ of all cases [1]. In an attempt to localize a common region of loss in these tumours, we carried out an allelotyping analysis of 25 glioblastomas multiforme, 6 astrocytomas, 4 oligodendrogliomas and 2 ependymomas using highly polymorphic DNA markers, located in the q26 region of chromosome 10. Two meningioma samples have also been analysed. Loss of heterozygosity was found in $76 \%$ $(19 / 25)$ of the glioblastomas, $50 \%(3 / 6)$ of the astrocytomas, $50 \%(2 / 4)$ of the oligodendrogliomas and 100\% (2/ 2) of the ependymomas. None of the two meningiomas showed evidence of loss in this region. The allelotyping results revealed a minimal common region of loss, bordered by the D10S1236 and D10S186 markers, spanning $8.88 \mathrm{Mb}$, which may be a possible location for a tumour suppressor gene involved in human glioma progression. This region may also be associated to glioma tumorigenesis, since it also appears deleted in early stage gliomas. The fact that microsatellite instability (MSI) screening of gliomas has rendered only one positive sample shows that there is little evidence of MSI for one of the analysed markers, suggesting that this is not a significant event in the tumorigenesis of these malignancies.

\section{Author details}

${ }^{1}$ Faculdade de Farmácia Universidade de Lisboa, Lisboa, Portugal. ${ }^{2} \mathrm{CIMAGO}$

Faculdade de Medicina, Universidade de Coimbra, Coimbra, Portugal.

${ }^{3}$ Hospital de São José CHLC, Serviço de Anatomia Patológica, Lisboa,

\footnotetext{
* Correspondence: cm@ff.ul.pt

${ }^{1}$ Faculdade de Farmácia Universidade de Lisboa, Lisboa, Portugal
}

Full list of author information is available at the end of the article
Portugal. ${ }^{4}$ INFARMED, I.P., Parque de Saúde de Lisboa, Lisboa, Portugal. ${ }^{5}$ Cancer Research UK Cambridge Research Institute and Department of Oncology, University of Cambridge, Cambridge, Reino Unido. ${ }^{6}$ Université Paul Verlaine, Laboratoire d'Ingénierie Moléculaire et Biochimie

Pharmacologique, Metz, França. ${ }^{7}$ Faculdade de Medicina da Universidade de Coimbra, Laboratório de Citogenética, Instituto de Biologia Médica, Coimbra, Portugal. ${ }^{8}$ Escola Superior de Tecnologia da Saúde de Lisboa, Lisboa, Portugal.

Published: 24 September 2010

\section{Reference}

1. Arslantas A, Artan S, Oner U, Müslümanoglu MH, Ozdemir M, Durmaz R, Arslantas D, Vural M, Cosan E, Atasoy MA: Genomic alterations in lowgrade, anaplastic astrocytomas and glioblastomas. Pathol Oncol Res 2007, 13:39-46.

\section{doi:10.1007/BF02893439}

Cite this article as: Alves et al.: Identification of a common deletion region in 10q26 associated with human gliomas. BMC Proceedings 2010 4(Suppl 2):P62.
Submit your next manuscript to BioMed Central and take full advantage of:

- Convenient online submission

- Thorough peer review

- No space constraints or color figure charges

- Immediate publication on acceptance

- Inclusion in PubMed, CAS, Scopus and Google Scholar

- Research which is freely available for redistribution

Submit your manuscript at www.biomedcentral.com/submit
C Biomed Central 